\title{
KEEFEKTIFAN MODEL PEMBELAJARAN ISK DAN DI DITINJAU DARI MOTIVASI, SIKAP, DAN KEMAMPUAN KOMUNIKASI MATEMATIS
}

\author{
Djuwita Amin Mahmud ${ }^{1)}$, Hartono ${ }^{2)}$ \\ Universitas Muhammadiyah Maluku Utara ${ }^{1)}$, Universitas Negeri Yogyakarta ${ }^{2)}$ \\ djuwitaamin@yahoo.co.id ${ }^{1)}$, hartono@uny.ac.id ${ }^{2)}$
}

\begin{abstract}
Abstrak
Penelitian ini bertujuan untuk mendeskripsikan keefektifan dan perbedaan keefektifan model pembelajaran interaktif setting kooperatif dengan direct instruction ditinjau dari motivasi belajar, sikap, dan kemampuan komunikasi matematis. Populasi penelitian ini adalah siswa kelas X SMA Negeri 3 Ternate yang terdiri dari 5 kelas. Dari populasi yang ada diambil secara acak dua kelas yaitu kelas X-1 dan X-3 sebagai sampel penelitian. Kelas X-1 diberi treatment dengan model pembelajaran interaktif setting kooperatif, sedangkan kelas X-3 dengan model direct instruction. Data penelitian dianalisis dengan statistik uji one sampel t-test, uji MANOVA dengan $\mathrm{T}^{2}$ Hotelling's pada taraf signifikan 0,05 dan uji univariat untuk menentukan model mana yang lebih efektif. Hasil penelitian menunjukkan bahwa: (1) pembelajaran matematika dengan model pembelajaran interaktif setting kooperatif efektif ditinjau dari motivasi belajar, sikap, dan komunikasi matematis sedangkan pada model pembelajaran direct instruction efektif ditinjau dari motivasi belajar dan sikap belajar siswa tetapi tidak efektif ditinjau dari komunikasi matematis; (2) terdapat perbedaan keefektifan antara model pembelajaran interaktif setting kooperatif dengan direct instruction. Model pembelajaran interaktif setting kooperatif lebih efektif daripada model direct instruction ditinjau dari motivasi belajar, sikap, dan kemampuan komunikasi matematis siswa kelas X SMA Negeri 3 Ternate.
\end{abstract}

Kata Kunci: Model pembelajaran interaktif setting kooperatif, direct instruction, motivasi belajar, sikap, dan kemampuan komunikasi matematis.

\section{THE EFFECTIVENESS OF THE MODEL ISK AND DI IN TERMS OF MOTIVATION, ATTITUDE, AND MATHEMATICAL COMMUNICATION SKILL}

\begin{abstract}
This study aims to describe the effectiveness and the differences of the effectiveness between the model of interactive learning with cooperative setting and the direct instruction in terms of learning motivation, attitudes, and mathematical communication skill. The research population was a Class $X$ student of SMA Negeri 3 Ternate which consisted of 5 classes. Out of the population was drawn at random two classes namely Class $X-1$ and Class $X-3$ as the research sample. Class $X-1$ was treated with the model of interactive learning with cooperative setting, while Class $X-3$ was treated with the model of direct instruction. The data were analyzed using one sample t-test, MANOVA with $T^{2}$ Hotelling's at significant level of 0.05 and univariate analysis to determine which model is more effective. The results of the study show that: (1) learning mathematics with the model of interactive learning with cooperative setting is effective in the context of learning motivation, attitudes, and mathematical communication skill, meanwhile the model of learning with direct instruction is effective in terms of learning motivation and attitude but ineffective in the context of mathematical communication skill; (2) there is a difference between the effectiveness of the model of interactive learning with cooperative setting and direct instruction. The model of interactive learning with cooperative setting is more effective compared to direct instruction in terms of learning motivation, attitudes, and mathematical communication skill of students of class X, SMA 3 Ternate.
\end{abstract}

Keywords: Model of interactive learning with cooperative setting, direct instruction, learning motivation, attitudes, and mathematical communication skill. 


\section{PENDAHULUAN}

Pendidikan Nasional Indonesia bertujuan untuk mengembangkan potensi peserta didik. Sebagaimana tercantum dalam Undang-undang bahwa pendidikan adalah usaha sadar dan terencana untuk mewujudkan suasana belajar dan proses pembelajaran agar peserta didik secara aktif mengembangkan potensi dirinya utuk memiliki kekuatan spiritual keagamaan, pengendalin diri, kepribadian, kecerdsan, ahlak mulia, serta keterampilan yang diperlukan dirinya, masyarakat, bangsa, dan negara (UU No. 20 tahun 2003).

Pembelajaran juga merupakan ujung tombak dalam proses pendidikan disekolah, sehingga pembelajaran yang berlangsung dalam rangka mencapai tujuan kompetensi lulusan bukan hanya berlangsung untuk mentransfer ilmu pengetahuan dari guru ke siswa saja tetapi bagaimana siswa juga terlibat aktif pada proses pembelajaran. Aktifnya siswa dalam pembelajaran dapat membantunya menemukan, mengembangkan, memecahkan masalah, dan mengkomunikasikan ide-ide yang dia miliki sekaligus bisa memupuk minat dan sikap positif serta menumbuhkan motivasi tinggi saat pembelajaran berlangsung. Hal ini sesuai dengan standart proses pembelajaran yang telah diatur dalam Peraturan Menteri Pendidikan Nasional Nomor 41 tahun 2007, disebutkan bahwa proses pembelajaran pada satuan pendidikan diselenggarakan secara interaktif, inspiratif, menyenangkan, menantang, memotivasi peserta didik untuk berpartisipasi aktif, serta memberikan ruang yang cukup bagi prakarsa, kreativitas, dan kemandirian sesuai dengan bakat, minat, dan perkembangan fisik serta psikologi peserta didik. Dalam proses tersebut diperlukan guru yang memberikan keteladanan, membangun kemauan, dan mengembangkan potensi dan kreativitas peserta didik.

Matematika adalah salah satu pelajaran yang diajarkan di sekolah, dimana matematika merupakan mata pelajaran yang penting baik untuk bidang ilmu lain maupun matematika itu sendiri. Matematika merupakan bagian dari ilmu pengetahuan yang aspek terapan maupun penalarannya banyak di manfaatkan diberbagai bidang terutama teknologi. Hal ini disebutkan dalam lampiran penjelasan Peraturan Menteri Pendidikan Nasional Nomor 22 tahun 2006 tentang standart kompetensi dan kompetensi dasar mata pelajaran matematika bahwa perkembangan pesat dibidang teknologi informasi dan komunikasi dewasa ini dilandasi oleh perkembangan matematika di bidang teori bilangan, aljabar, analisis, teori peluang, dan matematika diskrit. Selain itu, dalam Principle and Standards for School Mathematics, (2000, p.66) juga disebutkan bahwa " mathematics is used in science, the social siance, medicine, and commerce". Pernyataan tersebut menyatakan bahwa matematika juga digunakan dalam ilmu pengetahuan, pengetahuan sosial, kesehatan, dan perdagangan.

Uraian tersebut menggambarkan bahwa matematika merupakan ilmu pengetahuan yang bermanfaat bagi kehidupan sehingga matematika penting untuk dipelajari. Namun, objek matematika yang abstrak dan sarat dengan simbol maupun istilah matematis seringkali membuat siswa merasa kesulitan untuk mempelajari matematika. Tidak jarang ada siswa yang mampu memahami materi dengan baik namun tidak mampu mengaplikasikan materi tersebut pada masalah yang lebih kompleks. Hal ini mengindikasikan bahwa siswa mengalami masalah yang berkaitan dengan kemampuan komunikasi matematis.

Komunikasi matematis merupakan kecakapan siswa untuk menyatakan dan menafsirkan gagasan matematis secara lisan, tertulis, atau mendemonstrasikan apa yang ada dalam persoalan matematika. Dengan memiliki kemampuan komunikasi matematis yang baik, maka ide-ide matematis siswa dapat direfleksikan, diperbaiki, didiskusikan, dan dikembangkan. Proses komunikasi juga membantu siswa dalam membangun pemahaman dan keyakinan atas suatu ide. Relevan dengan ini dinyatakan dalam Principle and Standards for School Mathematics bahwa:

Communication is an essential par of mathematics and mathematics education. It is a way of sharing ideas and clarifying understanding. Through communication, ideas become objects of reflection, refinement, discussion, and amendment. The communication prosess also helps build meaning and permanence for ideas and makes them public. When student are challenged to think and reason about mathematics and communication the results of their thinking to others orally or in writing, they learn to be clear and convincing. NCTM (2000, p.60)

Dari kutipan tersebut diperoleh pengertian bahwa pada saat siswa ditantang untuk berpikir 
dan berdiskusi tentang matematika, dan selanjutnya mengomunikasikan pemikiran mereka kepada siswa lain baik secara lisan maupun tulisan, mereka belajar untuk lebih jelas dan meyakinkan dalam memberi alasan-alasan tentang suatu ide.

Selanjutnya NCTM (2000, p.61) juga menyebutkan bahwa "Communication can support student' learning of new mathematical concepts as they act out a situation, draw, use objects, give verbal accounts and explanations, use diagrams, write and use mathematical symbols". Dengan demikian maka komunikasi juga mendukung siswa agar memiliki pemahaman yang baik terhadap konsep yang dipelajari sehingga mampu memecahkan masalah yang berkaitan dengan konsep tersebut, oleh karena itu maka komunikasi matematis perlu dikembangkan dalam diri siswa untuk mendukung peningkatan hasil belajarnya.

Keberhasilan pendidikan di sekolah ditentukan oleh siswa itu sendiri, guru dan model pembelajaran yang tepat. Model pembelajaran berperan penting dalam pembelajaran disebabkan karena model mengajar dijadikan sebagai kerangka konseptual yang mendeskripsikan dan melukiskan prosedur yang sistimatik dalam mengorganisasikan pengalaman belajar dan pembelajaran untuk mencapai tujuan tertentu, dan berfungsi sebagai pedoman bagi perencanaan pengajaran bagi para guru dalam melaksanakan aktivitas pembelajaran (Sagala, 2010, p.176).

Permendiknas Nomor 22 tahun 2006 tentang tujuan mata pelajaran matematika diajarkan di sekolah antara lain agar peserta didik memiliki kemampuan: (1) memahami konsep dan menjelaskan keterkaitan dan mengaplikasikan konsep secara luwes, akurat, efisien, dan tepat dalam pemecahan masalah. (2) menggunakan penalaran, melakukan manipulasi dalam membuat generalisasi, menyusun bukti atau menjelaskan gagasan dan pernyataan matematika. (3) Memecahkan masalah meliputi memahami masalah, merancang dan menyelesaikan model dan menafsirkan solusi. (4) mengomunikasikan gagasan dan simbol, tabel, diagram atau media lain untuk memperjelas keadaan dan masalah. (5) memiliki sikap menghargai kegunaan matematika dalam kehidupan.

Salah satu kemampuan yang diharapkan dikuasai oleh siswa sebagai hasil dari proses pembelajaran matematika berdasarkan permendiknas tersebut adalah kemampuan komunikasi. Di mana pembelajaran yang dilaksanakan di sekolah perlu mempertimbangkan aspek siswa merupakan makhluk individu yang memiliki perbedaan jenis kelamin, agama, kemampuan akademik, harapan dan lain sebagainya antara siswa yang satu dengan siswa yang lainnya. Berangkat dari hal tersebut siswa tentunya harus menjadi makhluk sosial yang membutuhkan interaksi dengan orang lain untuk melengkapi hidupnya. Dalam kehidupan sosial tersebut siswa berkomunikasi dan bekerja sama dengan orang di sekitar khususnya guru dan temantemannya untuk mencapai tujuan hidupnya. Oleh karena itu, pembelajaran yang dilaksanakan di sekolah perlu mempertimbangkan aspek siswa sebagai makhluk sosial yang membutuhkan komunikasi dalam mempelajari dan memahami materi pelajaran.

Meskipun demikian, sangat disayangkan bahwa proses pembelajaran matematika yang berlangsung di Indonesia pada umumnya dikemukakan Mahmudi (2009, p.1) adalah pembelajaran matematika lebih difokuskan pada aspek komputasi yang bersifat algoritmik. Tidak mengherankan bila berdasarkan berbagai studi menunjukan bahwa siswa pada umumnya dapat melakukan berbagai perhitungan matematik, tetapi kurang menunjukan hasil yang menggembirakan terkait penerapannya dalam kehidupan sehari-hari. Pembelajaran matematika hendaknya tidak hanya mencangkup berbagai penguasaan konsep matematika, melaikan juga terkait dengan aplikasinya dalam kehidupan nyata seperti mengoleksi, menyajikan, menganalisis dan menginterpretasikan data, serta mengkomunikasikannya sangat perlu untuk dikuasai siswa.

Bagi dunia keilmuan, matematika merupakan bahasa simbolik yang memungkinkan terjadinya komunikasi yang cermat dan tepat. Selain pengembangan kemampuan komunikasi matematis, pembelajaran juga harus dapat menumbuhkan motivasi belajar dan sikap siswa terhadap matematika. Pembelajaran yang dilakukan oleh guru tentunya akan berhasil jika didukung oleh siswa yang memiliki sikap positif dan motivasi untuk belajar. Menurut Goldin \& Sheteingold (NCTM 2000, p.19), motivasi merupakan hal penting sebagai penentu keberhasilan siswa dalam pembelajaran matematika. Siswa yang memiliki motivasi untuk terlibat dalam pembelajaran akan memilih tugas sesuai dengan kemampuannya, dan segera memulai kegiatan ketika diberi kesempatan, serta mengerahkan usaha intensif dan konsentrasi dalam pelaksanaan tugas-tugas belajar. Siswa seperti 
itu umumnya akan menunjukkan sikap dan emosi positif selama kegiatan berlangsung, berupa antusiasme, optimisme, rasa ingin tahu, dan minat.

Sikap yang positif terhadap matematika juga merupakan pengimbang untuk mencapai kompetensi dan hasil belajar matematika yang baik. Sebagaimana (Popham 1995, p.179) menyatakan ranah afektif menentukan keberhasilan belajar siswa. Keberhasilan pembelajaran pada ranah kognitif dan psikomotor dipengaruhi oleh kondisi afektif siswa. Salah satu kondisi afektif tersebut adalah sikap. Oleh karena itu, dalam proses pembelajaran matematika perlu memperhatikan hal-hal yang mempengaruhi sikap siswa terhadap matematika, antara lain materi dan karakteristik matematika itu sendiri, praktek mengajar, aktivitas yang terjadi di dalam kelas, dan guru matematika (Shunway 1980, p.359).

Pembelajaran matematika di sekolah, guru merasa kesulitan menerapkan model pembelajaran yang menjadikan siswa aktif di dalam mengikuti kegiatan belajar mengajar di kelas. Hal ini dapat dilihat dari praktek pembelajaran matematika di kelas, seringkali di dalam proses pembelajaran guru bertanya tentang konsep matematika yang sedang dibahas, banyak siswa yang diam sambil menundukkan kepala dan hanya beberapa siswa tertentu yang berani mencoba menjawab, kemudian siswa diminta untuk menanyakan hal yang menjadi kesulitannya, keadaan kelas menjadi sunyi (siswa diam). Terlebih lagi jika siswa diberi tugas di kelas maupun tugas rumah untuk mengerjakan soal, banyak siswa yang hanya menyalin pekerjaan temannya dan jarang ditemukan ide-ide baru siswa dalam menyelesaikan masalah matematika.

Salah satu tugas seorang guru adalah memotivasi siswa dalam proses pembelajaran. Sebagaimana diatur dalam Peraturan Menteri Pendidikan Nasional No. 41 tahun 2007, tugas seorang guru dalam pembelajaran matematika adalah memotivasi siswa untuk belajar. Sebab untuk membangkitkan motivasi siswa dibutuhkan minat dari siswa terhadap topik yang akan dipelajari. Karena motivasi sangat penting dalam belajar untuk keberhasilan suatu proses pembelajaran. Dimana keberhasilan suatu proses pembelajaran ditunjukan dengan terjadinya peningkatan motivasi, perubahan sikap, dan prilaku serta peningkatan status pengetahuan dari tidak tahu menjadi tahu.

Motivasi dapat dibangun melalui berbagai kegiatan-kegiatan yang menarik, menantang, dan menyenangkan untuk siswa. Kegiatan tersebut perlu mempertimbangkan unsur bermain dalam pembelajaran matematika. Hal ini sesuai dengan tahap perkembangan anak-anak yang cenderung lebih suka bermain dalam kelompoknya. Hal tersebut berhubungan dengan karakteristik siswa sekolah menengah seperti yang dikatakan Ebbutt \& Straker (Depdiknas, 2006) yang berpendapat bahwa potensi siswa dapat berkembang dan dapat mempelajari matematika secara optimal, apabila siswa memiliki motivasi belajar dan belajar melalui kerja sama dalam kelompok. Motivasi yang kuat dalam diri siswa akan meningkatkan minat, kemauan dan semangat yang tinggi dalam belajar, karena antara motivasi dan semangat belajar mempunyai hubungan yang erat. Sebagaimana yang dikatakan oleh Syaiful Sagala (2010, p.104) bahwa untuk memperlancar proses pembelajaran harus ada motivasi, sebab motivasi merupakan faktor yang sangat besar pengaruhnya pada proses belajar siswa, tanpa adanya motivasi, maka proses belajar siswa akan sukar dan tidak lancar. Dalam konsep pembelajaran motivasi berarti seni mendorong peserta didik untuk terdorong melakukan kegiatan belajar sehingga tujuan pembelajaran tercapai.

Dalam kenyataannya di lapangan, harapan yang diuraikan tersebut belum bisa terwujud dalam pembelajaran matematika. Pembelajaran matematika sekolah di tingkat dasar dan menengah merupakan pelajaran wajib bagi siswa selama berada di bangku sekolah. Namun sampai saat ini pembelajaran matematika bagi siswasiswa di sekolah menengah atas merupakan pelajaran yang dipandang sulit dan tidak disenangi oleh sebagian besar siswa. Inilah paradigma pembelajaran matematika yang selama ini terjadi pada kebanyakan sekolah. Bagi siswa yang mempunyai minat dan mampu mempelajari konsep matematika merupakan anugerah, sehingga mereka merasa senang dan nyaman mengikuti pembelajaran matematika, sedangkan bagi siswa yang tidak senang dengan matematika terasa merupakan musibah yang harus diikuti dengan terpaksa selama ia berada di sekolah tersebut.

Menurut Van De Walle (2008, pp.12-13), secara umum pembelajaran matematika masih menggunakan pengajaran tradisional yang biasanya dimulai dengan penjelasan tentang ideide yang terdapat pada halaman buku yang dipelajari, kemudian diikuti dengan menunjukan kepada siswa bagaimana mengerjakan latihan soal. Bahkan ketika siswa berkegiatan gurunya 
masih menuntun siswa bagaimana menggunakan materi yang dipelajari untuk mengerjakan latihan. Paradigma lama yang masih melekat dan tetap dipertahankan karena kebiasaan yang susah diubah tersebut masih tetap berlangsung sehingga belum berubah menjadi paradigma membelajarkan siswa. Proses pembelajaran tersebut lebih diarahkan pada pemberian tuntunan bagi siswa agar bisa menyelesaikan latihan soal yang diberikan sesuai dengan prosedur yang telah diajarkan. Hal tersebut diperparah oleh pandangan siswa secara umum tentang susahnya belajar matematika dan pandangan bahwa guru merupakan orang yang paling pintar dalam matematika sehingga ketika menyelesaikan soal, siswa mengikuti pola atau aturan yang diajarkan guru dan guru adalah penentu kebenaran dari soal yang dikerjakan.

Kualitas pendidikan yang guru berikan kepada siswa sangat tergantung pada apa yang guru lakukan di dalam kelas. Dengan demikian dalam mempersiapkan siswa untuk menjadi individu yang sukses di masa depan, guru matematika perlu yakin bahwa pembelajaran mereka yang dilaksanakan efektif (Zakaria \& Iksan 2007, p.35).

Selain faktor guru, ada berbagi faktor termasuk faktor siswa itu sendiri. Berdasarkan hasil penelitian Brown \& McNamara (2011, p.122) dalam pembelajaran matematika, beberapa siswa menunjuk kesulitan untuk mengkomunikasi gagasan matematis. Sedangkan dalam hubungan dengan motivasi, Santrock (2008, p.437) menyatakan bahwa motivasi merupakan aspek penting dari kegiatan pembelajaran, siswa yang tidak termotivasi tidak menggunakan waktu dan usaha untuk belajar. Menurut Sanjaya (2010, p.54), siswa yang tergolong berkemampuan tinggi biasanya ditunjukkan dengan motivasi belajar yang tinggi. Sebaliknya siswa yang tergolong kemampuan rendah ditunjukkan dengan motivasi belajar yang kurang. Motivasi diibaratkan sebagai bahan bakar yang menggerakan siswa untuk belajar.

Menurut Muijs \& Reynolds (2005, p.95) menyebutkan faktor-faktor yang dapat mempredisposisikan perilaku buruk siswa dapat terletak baik pada situasi-situasi di luar sekolah, seperti perkembangan psikologis siswa, maupun faktor-faktor di sekolah dan di kelas seperti kebosanan, pelajaran dan kurikulum yang tidak relevan, dan aturan yang terlalu longgar atau terlalu otoritarian. Jadi perlu dirancang pembelajaran yang beragam dan bervariasi yang dapat membantu mencegah terjadi perilaku dan sikap siswa yang kurang baik.

Matematika dapat dipahami siswa sangat tergantung pada interaksi maupun kerja sama antara guru dan siswa. Guru harus dapat memberikan pembelajaran yang efektif dan menyenangkan bagi siswa serta melibatkan siswa secara aktif dalam mengkonstruksi pengetahuan. Siswa juga harus mampu melibatkan dirinya dengan usaha dan pengetahuannya dalam mempelajari matematika. Jika salah satunya pasif atau tidak ada interaksi yang baik maka akan timbul permasalahan-permasalahan dalam matematika seperti: pembelajaran matematika terasa monoton atau tidak menyenangkan bagi siswa, hasil belajar matematika rendah, kesulitan siswa dalam mempelajari matematika, kemampuan berpikir siswa rendah baik penalaran, kritis maupun kreatif, pemahaman siswa sedikit, sikap siswa terhadap matematika negatif dan sebagainya.

Melihat fakta-fakta yang masih jauh dari harapan, maka harus dilakukan upaya-upaya untuk memperbaiki sistem pembelajaran matematika di Indonesia yang masih belum optimal, maka tenaga pendidik harus melakukan suatu inovasi pembelajaran yang mampu menciptakan suatu kondisi yang memungkinkan siswa lebih aktif, interaktif, bebas mengemukakan pendapat, saling membantu, dan bekerja sama dengan teman sebaya dalam menyelesaikan masalah untuk memperoleh pengetahuan baru. Hal ini sesuai dengan pernyataan NCTM (2000, p.61) bahwa " to support classroom discourse effectively, teachers must build a community in which students will feel free to express their ideas." Dengan demikian maka guru dapat memfasilitasi proses belajar mengajar dengan menggunakan cara-cara mengajar yang menjadikan informasi bermakna bagi siswa.

Kondisi yang memungkinkan munculnya hal-hal tersebut dalam pembelajaran adalah belajar dalam kelompok-kelompok kecil yang disebut dengan pembelajaran kooperatif dan dalam pembelajaran tersebut diciptakan situasi yang membuat siswa aktif dan interaktif secara luas serta mendekatkan matematika dengan kehidupan siswa itu sendiri. Model yang sesuai dengan karakteristik tersebut salah satunya adalah model pembelajaran interaktif setting kooperatif.

Model pembelajaran interaktif setting kooperatif adalah model kolaborasi pembelajaran interaktif dengan setting kooperatif yang di dalam proses pembelajarannya diciptakan forum 
diskusi yang diikuti oleh semua siswa secara aktif dan interaktif di dalam kelas dalam bentuk kelompok-kelompok kecil dimana dalam proses tersebut siswa juga mempunyai peran yang tidak kalah penting dengan peran guru. Dengan adanya diskusi dan tukar pendapat antar teman pasangannya dalam suatu kelompok yang kemudian dapat diperluas dan di kembangkan dengan kelompok lain memberi peluang bagi siswa dalam pembelajaran untuk mengkonstruksi pengetahuan baik yang telah ada maupun yang baru saja diperolehnya dengan cepat. Model pembelajaran interaktif dengan setting kooperatif juga memberikan penekanan pada interaksi secara luas yakni interaksi siswa-siswa, siswa-bahan ajar, siswa-guru, siswa-bahan ajarsiswa, serta siswa-bahan ajar-guru. Sebab interaksi ini sangat penting bagi upaya konstruksi pengetahuan, peningkatan kemampuan akademis, peningkatan interaksi sosial dan lain-lain.

Model pembelajaran lain yang digunakan dalam upaya untuk mengatasi permasalahanpermasahan tersebut adalah model direct instruction. Menurut Killen (2009, p.118) mendefinisikan direct instruction menyediakan informasi yang sepenuhnya menjelaskan konsep dan prosedur yang diperlukan siswa untuk belajar serta mendukung srategipembelajaran yang mampu bersaing dengan arsitektur kognitif manusia. direct instruction adalah pendekatan yang efektif dalam mengenalkan siswa pada konsep yang baru mereka kenal karena siswa perlu bimbingan yang hati-hati dalam membagun makna dan pengalaman belajar mereka.

Berdasarkan uraian di atas, maka terdapat beberapa persoalan yang perlu diperhatikan diantaranya motivasi belajar siswa rendah, sikap siswa terhadap matematika yang kurang menyenangkan dan komunikasi matematis siswa yang masih kurang sehingga prestasi siswa menurun, oleh karena itu diperlukan pengkajian untuk mendapatkan solusi yang dapat mengatasinya. Mengingat proses pembelajaran sangat besar pengaruhnya dalam menentukan keberhasilan siswa, maka perlu dilakukan penelitian Keefektifan Model Pembelajaran Interaktif Setting Kooperatif dan Direct Instruction Ditinjau dari Motivasi Belajar, Sikap Siswa Terhadap Matematika, dan Kemampuan Komunikasi Matematis Siswa dalam pembelajaran matematika.

\section{METODE}

Penelitian ini diklasifikasikan sebagai penelitian eksperimen semu (quasi eksperiment) dengan menggunakan dua kelas eksperimen yang ekuivalen. Desain penelitian yang digunakan adalah pretest-postest non ekuivalen group design. Penelitian ini dilaksanakan di SMA Negeri 3 Ternate tahun pelajaran 2012/2013, dari bulan April sampai dengan bulan Juni 2013. Populasi dari penelitian adalah seluruh siswa kelas X di SMA Negeri 3 Ternate tahun pelajaran 2012/2013 yang tersebar dalam lima kelas paralel yang kemampuan siswanya relatif tidak berbeda secara signifikan. Dengan demikian sampel yang diambil secara acak dua kelas dari lima kelas yang ada, sehingga diperoleh kelas $\mathrm{X}-1$ sebagai kelompok ekperimen satu dan X-3 sebagai kelompok ekperimen dua. Selanjutnya kelas X-1 diberikan treatment dengan model pembelajaran interaktif setting kooperatif dan kelas X-3 diberikan treatment dengan model pembelajaran direct instruction.

Penelitian ini melibatkan dua variabel, yaitu variabel bebas dan variabel terikat. dan pada pengukuran (posttest) terdapat tiga variabel terikat. Variabel bebas adalah model pembelajaran yang terdiri dari dua model yakni model pembelajaran interaktif setting kooperatif (ISK) dan model pembelajaran direct instruction (DI). Sedangkan yang merupakan variabel terikat adalah motivasi belajar siswa, sikap siswa terhadap matematika, dan kemampuan komunikasi matemtis.

Teknik pengumpulan data adalah tahapan yang digunakan peneliti dalam mengumpulkan data. Data dalam penelitian ini diperoleh langsung peneliti dengan memberikan treatment pada kedua kelas eksperimen. Teknik-teknik yang digunakan dalam penelitian ini adalah sebagi berikut: (a) Membuat instrumen penelitian yang berupa rencana pelaksanaan pembelajaran (RPP), lembar kegiatan siswa (LKS), kisi-kisi soal pretest dan posttest, rubrik penskoran sesuai dengan variabel yang akan diteliti, dan angket motivasi belajar serta sikap siswa terhadap matematika; (b) Meminta beberapa dosen ahli untuk memvalidasi instrumen penelitian yang telah dibuat; (c) Uji coba instrumen yang telah divalidasi pada 35 siswa kelas $\mathrm{X}$ SMA Negeri 5 Ternate; (d) Memberikan angket motivasi belajar dan sikap siswa terhadap matematika kepada siswa untuk diisi sebelum dilakukan pretest; (e) Melakukan pretest kemampuan komunikasi matematis sebelum dilakukan treatment; (f) Memberikan angket motivasi belajar dan sikap siswa terhadap matematika kepada siswa untuk diisi sebelum dilakukan posttest; (g) Memberikan posttest 
kemampuan komunikasi matematis setelah dilakukan treatment.

Pengumpulan data untuk instrumen non tes mengenai motivasi belajar dan sikap siswa terhadap matematika diperoleh dengan menggunakan angket yang berbentuk checklist dengan skala likert. Angket motivasi belajar dan sikap siswa terhadap matematika terdiri atas 20 butir, dan data untuk instrumen tes mengenai kemampuan komunikasi matematis berupa tes uraian (essay) sebanyak 3 item yang diberikan kepada siswa dalam batas waktu 90 menit.

Setelah memperoleh data pengukuran motivasi belajar matematika dan sikap siswa terhadap matematika, total skor motivasi belajar matematika dan sikap siswa terhadap matematika dikategorikan berdasarkan kriteria yang sudah ditetapkan. Untuk setiap pernyataan, responden akan diberikan skor sesuai dengan nilai skala kategori jawaban yang diberikannya berdasarkan kategori tingkat motivasi belajar dan sikap siswa terhadap matematika yang telah disesuaikan dengan skala yang ditentukan.

Adapun klasifikasi kriteria motivasi belajar siswa dan sikap siswa terhadap matematika sesuai pedoman klasifikasi Azwar (2011, p.163) sebagai berikut.

Tabel 1. Kriteria Motivasi Belajar Siswa

\begin{tabular}{cc}
\hline Interval & Kriteria \\
\hline $\mathrm{Mi}+1,5 \mathrm{Si}<\mathrm{X} \leq \mathrm{Mi}+3 \mathrm{Si}$ & Sangat Tinggi $(\mathrm{ST})$ \\
$\mathrm{Mi}+0,5 \mathrm{Si}<\mathrm{X} \leq \mathrm{Mi}+1,5 \mathrm{Si}$ & Tingggi $(\mathrm{T})$ \\
$\mathrm{Mi}-0,5 \mathrm{Si}<\mathrm{X} \leq \mathrm{Mi}+0,5 \mathrm{Si}$ & Sedang $(\mathrm{S})$ \\
$\mathrm{Mi}-1,5 \mathrm{Si}<\mathrm{X} \leq \mathrm{Mi}-0,5 \mathrm{Si}$ & Rendah $(\mathrm{R})$ \\
$\mathrm{Mi}-3 \mathrm{Si} \leq \mathrm{X} \leq \mathrm{Mi}-1,5 \mathrm{Si}$ & Sangat Rendah $(\mathrm{SR})$ \\
\hline
\end{tabular}

Keterangan:

$\mathrm{Mi}=$ Mean ideal

$\mathrm{Si}=$ Standar deviasi ideal

$\mathrm{X}=$ Skor perolehan

Tabel 2. Kriteria Sikap Siswa Terhadap Matematika

\begin{tabular}{cc}
\hline Interval & Kriteria \\
\hline $\mathrm{Mi}+1,5 \mathrm{Si}<\mathrm{X} \leq \mathrm{Mi}+3 \mathrm{Si}$ & Sangat Baik $(\mathrm{SB})$ \\
$\mathrm{Mi}+0,5 \mathrm{Si}<\mathrm{X} \leq \mathrm{Mi}+1,5 \mathrm{Si}$ & Baik $(\mathrm{B})$ \\
$\mathrm{Mi}-0,5 \mathrm{Si}<\mathrm{X} \leq \mathrm{Mi}+0,5 \mathrm{Si}$ & Cukup Baik $(\mathrm{CB})$ \\
$\mathrm{Mi}-1,5 \mathrm{Si}<\mathrm{X} \leq \mathrm{Mi}-0,5 \mathrm{Si}$ & Kurang Baik KB) \\
$\mathrm{Mi}-3 \mathrm{Si} \leq \mathrm{X} \leq \mathrm{Mi}-1,5 \mathrm{Si}$ & Sangat kurang baik \\
& (SKB) \\
\hline
\end{tabular}

Keterangan:

$\mathrm{Mi}=$ Mean ideal

$\mathrm{Si}=$ Standar deviasi ideal

$\mathrm{X}=$ Skor perolehan
Instrumen test mengenai kemampuan komunikasi matematis dalam penelitian ini terdiri atas soal pretest dan posttest berbentuk uraian sebanyak tiga item, yang digunakan untuk mengukur kemampuan komunikasi matematis sebelum treatment dan setelah treatment.

\section{Teknik Analisis Data}

Analisis deskriptif digunakan untuk mendeskripsikan karakteristik data hasil penelitian dan menjawab permasalahan deskriptif. Analisis deskriptif yang digunakan dalam penelitian ini untuk data kemampuan komunikasi matematis, motivasi belajar dan sikap siswa terhadap matematika adalah nilai rerata, varians, standar deviasi, skor maksimum ideal, skor maksimum, dan skor minimum. Data penelitian yang dianalisis adalah data hasil pretest dan posttest pada aspek kemampuan komunikasi matematis dan hasil pengisian angket motivasi belajar dan sikap siswa terhadap matematika.

Untuk mengetahui keefektifan kedua model pembelajaran yang diterapkan ditinjau dari masing-masing aspek yaitu aspek motivasi belajar, sikap siswa terhadap matematika dan kemampuan komunikasi matematis siswa digunakan uji statistik one sample t-test. Data yang dianalisis untuk uji one sample t-test adalah data posttest. Uji asumsi yang harus dipenuhi adalah uji normalitas terhadap data angket motivasi belajar, sikap siswa terhadap matematika dan data posttest kemampuan komunikasi matematis siswa setelah treatment pada kedua kelompok, dengan menggunakan Kolmogorov-Smirnov. Kriteria data berdistribusi normal jika nilai signifikansinya lebih besar dari 0,05 . adalah:

Secara umum hipotesis statistik yang diuji

$\mathrm{H}_{0}: \mu \leq \mu_{0}$
$\mathrm{H}_{a}: \mu>\mu_{0}$

Dengan taraf signifikansi $\alpha=0,05$. Statistik uji one sample t-test dirumuskan:

$t=\frac{\bar{X}-\mu_{0}}{\frac{s}{\sqrt{n}}}$

Keterangan:

$\bar{X}=$ Nilai rata-rata

$\mu_{0}=$ Nilai yang dihipotesiskan

$\mathrm{s}=$ Simpangan baku sampel

$\mathrm{n}=$ Ukuran sampel

Kriteria keputusan yaitu tolak $\mathrm{H}_{\mathrm{o}}$ jika $\mathrm{t}_{\text {hitung }}>\mathrm{t}$ $\alpha ; n-1$ 
Untuk mengetahui perbedaan kondisi sebelum dan sesudah treatment dari kedua kelompok eksperimen ditinjau dari motivasi belajar, sikap siswa terhadap matematika dan kemampuan komunikasi matematis digunakan uji Multivariate of Variance (MANOVA) dengan bantuan soft ware SPSS 16 for windows. Data yang dianalisis dengan uji MANOVA adalah data pretest dan data posttest dari masing-masing variabel.

Uji asumsi yang harus dipenuhi adalah uji normalitas dan uji homogenitas terhadap data hasil pretest dan posttest kemampuan komunikasi matematis serta data angket motivasi belajar dan sikap siswa terhadap matematika sebelum dan setelah treatment pada kedua kelompok. Uji normalitas multivariat dilakukan dengan menggunakan jarak mahalanobis $d_{i}^{2}$. Jika jumlah dari $d_{i}^{2}$ yang kurang dari $\chi_{p}^{2}(0,5)$ sekitar $50 \%$, maka data berasal dari populasi normal multivariat.

Perhitungan statistik uji MANOVA menurut Stevens, dirumuskan sebagai berikut (2002, p.176):

$$
T^{2}=\frac{n_{1} n_{2}}{n_{1}+n_{2}}\left(\overline{y_{1}}-\overline{y_{2}}\right) S^{-1}\left(\overline{y_{1}}-\overline{y_{2}}\right)
$$

Keterangan:

$\mathrm{T}^{2}=$ Hottelling's trace

$\mathrm{n}_{1}=$ Banyaknya sampel pada kelompok I

$\mathrm{n}_{2}=$ Banyaknya sampel pada kelompok II

$\overline{y_{1}}=$ Vektor rata-rata skor kel eksperimen I

$\overline{y_{2}}=$ Vektor rata-rata skor kel eksperimen II

$\mathrm{S}^{-1}=$ Invers matriks kovarian

Setelah diperoleh nilai Hottelling's trace, kemudian ditransformasikan untuk memperoleh nilai distribusi $\mathrm{F}$ dengan menggunakan rumus :

$F=\frac{\left(n_{1}+n_{2}-p-1\right)}{\left(n_{1}+n_{2}-2\right) p} T^{2}$

dengan $p=3$ adalah banyaknya variabel dependen. Kriteria pengujiannya adalah $\mathrm{H}_{\mathrm{o}}$ ditolak jika $F_{\text {hitung }}>F_{\left(0,05 ; p, n_{1}+n_{2}-p-1\right)}$ atau angka signifikansi yang dihasilkan lebih kecil dari 0,05 .

Jika pada uji MANOVA diperoleh hasil uji kesamaan rata-rata (mean) skor pada setiap kelompok berbeda signifikan maka uji hipotesis selanjutnya adalah uji univariat dengan independen sample t-test.

Untuk mengetahui apakah pembelajaran dengan model pembelajaran ISK lebih efektif dari model pembelajaran DI ditinjau dari motivasi belajar, sikap siswa terhadap matematika, dan kemampuan komunikasi matematis siswa, digunakan statistik uji univarit (independent samples t-test). Uji asumsi yang harus dipenuhi adalah uji homogenitas dan uji normalitas terhadap motivasi belajar, sikap siswa terhadap matematika, dan kemampuan komunikasi matematis siswa setelah treatment pada kedua kelompok. Uji homogenitas menggunakan levene test dengan keriteria data homogen adalah jika nilai signifikansinya lebih besar dari 0,05 . Sedangkan uji normalitas menggunakan Kolmogorov-Smirnov dengan kriteria data berdistribusi normal jika nilai signifikansinya lebih besar dari 0,05 .

Kriteria yang digunakan adalah kriteria Benferroni dimana taraf signifikannya adalah $\alpha / p$ dengan $p$ adalah banyaknya variabel dependen (Stevens 2002, p.181). Kriteria pengujian $\mathrm{t}_{\text {hitung }}<\mathrm{t}_{\text {tabel }}$ maka $\mathrm{H}_{0}$ ditolak.

Rumus uji univariat yang digunakan menurut Stevens (2002, p.176) adalah:

$$
t=\frac{\overline{y_{1}}-\overline{y_{2}}}{\sqrt{\frac{\left(n_{1}-1\right) s_{1}^{2}+\left(n_{2}-1\right) s_{2}^{2}}{n_{1}+n_{2}-2}\left(\frac{1}{n_{1}}+\frac{1}{n_{2}}\right)}}
$$

Keterangan:

$\overline{y_{1}}=$ rata-rata kelompok I

$\overline{y_{2}}=$ rata-rata kelompok II

$s_{1}^{2}=$ varians kelompok I

$s_{2}^{2}=$ varians kelompok II

$\mathrm{n}_{1}=$ besar sampel dari kelompok I

$\mathrm{n}_{2}=$ besar sampel dari kelompok II

\section{HASIL DAN PEMBAHASAN}

\section{Deskripsi Data Hasil Penelitian}

Deskripsi data merupakan gambaran data yang diperoleh untuk mendukung pembahasan hasil penelitian. Setelalah seluruh kegiatan belajar mengajar dalam penelitian ini yang direncanakan berlangsung sebanyak tujuh kali pertemuan dilakukan, diberikan tes dan angket pada kedua kelas eksperimen.

Untuk memberikan gambaran kondisi sebelum dan setelah treatment hasil angket dan tes dari masing-masing aspek yaitu aspek motivasi belajar, sikap siswa terhadap matematika, dan kemampuan komunikasi matematis siswa dapat dilihat dari data berikut.

Data hasil angket motivasi belajar siswa dapat di sajikan pada Tabel.3 berikut. 
Tabel 3. Deskripsi Data Hasil Angket Motivasi Belajar Siswa

\begin{tabular}{ccccc}
\hline Model & \multicolumn{2}{c}{ ISK } & \multicolumn{2}{c}{ DI } \\
\hline Kondisi & pre & post & pre & post \\
\hline Rerata & 49,5 & 81,9 & 49,4 & 72,8 \\
Varians & 172 & 113 & 168 & 218 \\
SD & 13,1 & 10,6 & 12,9 & 12,9 \\
SMI & 100 & 100 & 100 & 100 \\
SMK & 75 & 100 & 75 & 100 \\
SMN & 27 & 58 & 23 & 48 \\
\hline
\end{tabular}

Ket:

$\mathrm{SD}=$ Standar Deviasi

SMI = Skor Maksimum Ideal

SMK $=$ Skor Maksimum

$\mathrm{SMN}=$ Skor Minimum

Berdasarkan hasil analisis data statistik deskriptif pada Tabel 3 menunjukan bahwa pada kelompok model ISK, terdapat pening-katan skor motivasi belajar siswa sebelum treatment dan setelah treatment. Ini menunjukkan bahwa rata-rata motivasi belajar siswa yang mengikuti proses pembelajaran dengan model ISK lebih baik dibandingkan dengan model DI.

Distribusi frekuensi data hasil angket motivasi belajar siswa untuk kedua kelompok ekperimen terlihat pada Tabel 4 berikut.

Tabel.4 Distribusi Frekuensi Motivasi Belajar Siswa Model ISK dan DI

\begin{tabular}{|c|c|c|c|c|c|c|c|c|}
\hline \multicolumn{4}{|c|}{ Pretest } & \multicolumn{4}{|c|}{ Postest } & \multirow{3}{*}{ Krit } \\
\hline \multicolumn{2}{|c|}{ ISK } & \multicolumn{2}{|c|}{ DI } & \multicolumn{2}{|c|}{ ISK } & \multicolumn{2}{|c|}{ DI } & \\
\hline $\mathbf{F}$ & $\%$ & $\mathbf{F}$ & $\%$ & $\mathbf{F}$ & $\%$ & $\mathbf{F}$ & $\%$ & \\
\hline 0 & 0 & 0 & 0 & 16 & 45,7 & 6 & 17,1 & ST \\
\hline 5 & 14,3 & 4 & 11,4 & 16 & 45,7 & 19 & 54,3 & $\mathrm{~T}$ \\
\hline 6 & 17,1 & 10 & 28,6 & 3 & 8,6 & 6 & 17,1 & S \\
\hline 12 & 34,3 & 11 & 31,4 & 0 & 0 & 3 & 8,6 & $\mathrm{R}$ \\
\hline 12 & 34,3 & 10 & 28,6 & 0 & 0 & 1 & 2,9 & SR \\
\hline
\end{tabular}

Berdasarkan Tabel 4 dapat diketahui bahwa pada kelompok model ISK setelah treatment secara kumulatif $91,43 \%$ siswa memiliki kategori motivasi belajar yang sangat tinggi dan tinggi, sedangkan Pada kelompok model DI sebesar $71,43 \%$ siswa yang memiliki kriteria motivasi belajar yang tinggi dan sangat tinggi, sehingga dapat dikatakan terdapat peningkatan motivasi belajar matematika siswa setelah treatment.

Selanjutnya secara singkat hasil angket sikap siswa terhadap matematika untuk kedua kelompok disajikan pada Tabel 5 berikut.

Tabel 5. Deskripsi Data Hasil Angket Sikap Siswa Terhadap Matematika

\begin{tabular}{ccccc}
\hline Model & \multicolumn{2}{c}{ ISK } & \multicolumn{2}{c}{ DI } \\
\hline Kondisi & pre & post & pre & post \\
\hline Rerata & 47,7 & 80,3 & 47,3 & 71,7 \\
varians & 173 & 113 & 169 & 169 \\
SD & 13,2 & 10,7 & 13,0 & 13,0 \\
SMI & 100 & 100 & 100 & 100 \\
SMK & 75 & 100 & 75 & 100 \\
SMN & 28 & 55 & 22 & 50 \\
\hline
\end{tabular}

Ket:

ISD $=$ Standar Deviasi

SMI = Skor Maksimum Ideal

SMK $=$ Skor Maksimum

$\mathrm{SMN}=$ Skor Minimum

Berdasarkan hasil analisis statistik deskriptif pada Tabel 5 menunjukkan bahwa pada kelompok model ISK, terdapat peningkatan skor sikap siswa terhadap matematika sebelum treatment dan setelah treatment. Ini menunjukkan bahwa rata-rata sikap siswa terhadap matematika yang mengikuti proses pembelajaran dengan model ISK lebih baik dibandingkan dengan model DI.

Distribusi frekuensi data hasil angket sikap siswa terhadap matematika untuk kedua kelompok ekperimen terlihat pada Tabel 6 berikut.

Tabel 6. Distribusi Frekuensi Sikap Siswa Terhadap Matematika Model ISK dan DI

\begin{tabular}{ccccccccc}
\hline & \multicolumn{2}{c}{ Pretest } & \multicolumn{8}{c}{ Postest } & \multirow{2}{*}{ Krit } \\
\cline { 1 - 8 } & ISK & & & DI & \multicolumn{1}{c}{ ISK } & DI & \\
\hline F & \% & F & \% & F & \% & F & \% & \\
\hline 0 & 0 & 0 & 0 & 19 & 54,3 & 6 & 17,1 & SB \\
0 & 0 & 0 & 0 & 12 & 34,3 & 16 & 45,8 & B \\
8 & 22,9 & 7 & 20 & 4 & 11,4 & 10 & 28,6 & CB \\
15 & 42,9 & 17 & 48,6 & 0 & 0 & 2 & 5,7 & KB \\
12 & 34,3 & 11 & 31,4 & 0 & 0 & 1 & 2,9 & SKB \\
\hline
\end{tabular}


Berdasarkan Tabel.6, dapat diketahui bahwa pada kelompok model ISK setelah treatment secara kumulatif $88,57 \%$ siswa memiliki kategori sikap siswa terhadap matematika yang sangat baik dan baik, sedangkan pada kelompok model DI sebesar 62,86\% siswa yang memiliki kriteria sikap siswa terhadap matematika yang baik dan sangat baik, sehingga dapat dikatakan terdapat peningkatan sikap siswa terhadap matematika setelah treatment.

Hasil tes kemampuan komunikasi matematis siswa pada kelompok model pembelajaran ISK dan model pembelajaran DI disajikan pada Tabel 7 berikut.

Tabel 7. Deskripsi Data Tes Kemampuan

Komunikasi Matematis Siswa Model Pembelajaran ISK dan DI

\begin{tabular}{lcccc}
\hline \multirow{2}{*}{ Deskripsi } & \multicolumn{2}{c}{ ISK } & \multicolumn{2}{c}{ DI } \\
\cline { 2 - 5 } & Pre & Post & Pre & Post \\
\hline Rerata & 34,9 & 80,3 & 33,4 & 66,0 \\
Varians & 246 & 133 & 259 & 277 \\
SD & 1,56 & 1,16 & 1,61 & 1,66 \\
SMI & 100 & 100 & 100 & 100 \\
SMK & 60 & 95 & 60 & 90 \\
SMN & 10 & 60 & 0 & 30 \\
\hline
\end{tabular}

Ket:

$\mathrm{SD}=$ Standar Deviasi

SMI $=$ Skor Maksimum Ideal

SMK $=$ Skor Maksimum

$\mathrm{SMN}=$ Skor Minimum

Berdasarkan hasil analisis data statistik deskriptif pada Tabel 7 terlihat bahwa rata-rata hasil tes kemampuan komunikasi matematis (postest) pada kedua kelompok setelah treatment hasilnya terjadi peningkatan kemampuan komunikasi matematis baik dikelompok model ISK maupun kelompok model DI dengan rentang peningkatan yang berbeda. Pada kelompok model ISK rata-rata skor meningkat sebesar 45,4 yaitu dari skor awal 34,9 menjadi 80,3. Sedangkan pada kelompok model DI peningkatan skor yang terjadi sebesar 32,6 yaitu dari skor awal 33,4 menjadi 66,0. Dengan demikian, dapat disimpulkan bahwa ada peningkatan kemampuan komunikasi matematis siswa pada kedua kelompok model tersebut, dan menunjukkan bahwa rata-rata kemampuan komunikasi matematis siswa yang mengikuti proses pembelajaran dengan model ISK lebih baik dibandingkan dengan model DI.

Data penelitian ini selanjutnya di analisis untuk mengetahui keefektifan dari masingmasing kelompok model pembelajaran maka dilakukan pengujian one sample t-test. Pengujian hipotesis menggunakan uji one sample t-test dapat dilakukan jika asumsi normalitas terpenuhi. Berdasarkan hasil uji normalitas menggunakan uji Kolmogorov-Smirnov, diperoleh hasil sebagai berikut.

Tabel 8. Hasil Uji Normalitas dengan Uji Kolmogorov-Smirnov

\begin{tabular}{ccc}
\hline Model & Variabel Terikat & $\begin{array}{c}\text { Kolmogorov- } \\
\text { Smirnov(Sig.) }\end{array}$ \\
\hline \multirow{2}{*}{ ISK } & Motivasi & 0,453 \\
& Sikap & 0,698 \\
& Kemkommat & 0,366 \\
DI & Motivasi & 0,437 \\
& Sikap & 0,484 \\
\hline
\end{tabular}

Tabel 8 menunjukkan bahwa semua nilai signifikansi lebih besar dari 0,05 . Hal ini menunjukan semua data berdistribusi normal. Oleh karena data berdistribusi normal, maka uji one sample t-test dapat dilakukan.

Terdapat enam uji hipotesis yang di uji dalam bagian ini, yakni:

$\mathrm{H}_{01}: \mu_{11} \leq 67$ (Pembelajaran matematika dengan model ISK tidak efektif ditinjau dari motivasi belajar siswa).

$\mathrm{H}_{\mathrm{a} 1}: \quad \mu_{11}>67$ (Pembelajaran matematika dengan model ISK efektif ditinjau dari motivasi belajar siswa).

$\mathrm{H}_{02}: \quad \mu_{21} \leq 67$ (Pembelajaran matematika dengan model ISK tidak efektif ditinjau dari sikap siswa terhadap matematika).

$\mathrm{H}_{\mathrm{a} 2}: \quad \mu_{21}>67$ (Pembelajaran matematika dengan model ISK efektif ditinjau dari sikap siswa terhadap matematika).

$\mathrm{H}_{03}: \quad \mu_{31} \leq 60$ (Pembelajaran matematika dengan model ISK tidak efektif ditinjau dari kemampuan komunikasi matematika siswa).

$\mathrm{H}_{\mathrm{a} 3}: \quad \mu_{31}>60 \quad$ (Pembelajaran matematika dengan model ISK efektif ditinjau dari kemampuan komunikasi matematika siswa).

$\mathrm{H}_{04}: \quad \mu_{12} \leq 67$ (Pembelajaran matematika dengan model DI tidak efektif ditinjau dari motivasi belajar siswa).

Ha4: $\mu_{12}>67$ (Pembelajaran matematika dengan model DI efektif ditinjau dari motivasi belajar siswa). 
H05: $\mu_{22} \leq 67$ (Pembelajaran matematika dengan model DI tidak efektif ditinjau dari sikap siswa terhadap matematika).

Ha5: $\mu_{22}>67$ (Pembelajaran matematika dengan model DI efektif ditinjau dari sikap siswa terhadap matematika).

H06: $\mu_{32} \leq 60$ (Pembelajaran matematika dengan model DI tidak efektif ditinjau dari kemampuan komunikasi matematika siswa).

Ha6: $\mu_{32}>60$ (Pembelajaran matematika dengan model DI efektif ditinjau dari kemampuan komunikasi matematika siswa).

Keterangan:

$\mu_{11}=$ Rata-rata skor motivasi belajar siswa pada model ISK

$\mu_{21}=$ Rata-rata skor sikap siswa terhadap matematika pada model ISK

$\mu_{31}=$ Rata-rata skor kemampuan komunikasi matematis siswa pada model ISK

$\mu_{12}=$ Rata-rata skor motivasi belajar siswa pada model DI

$\mu_{22}=$ Rata-rata skor sikap siswa terhadap matematika pada model DI

$\mu_{32}=$ Rata-rata skor kemampuan komunikasi matematis siswa pada model DI berikut.

Adapun hasil uji one sample t-test sebagai

Tabel 9. Hasil Uji One Sample t-test Motivasi

Belajar, Sikap Siswa terhadap Matematika, dan

Kemampuan Komunikasi Matematis Model

Pembelajaran ISK dan DI

\begin{tabular}{ccccc}
\hline ISK & $\mathbf{t}_{\text {hitung }}$ & $\boldsymbol{t}_{\text {tabel }}$ & $\mathbf{d f}$ & Signifikan \\
\hline Motivasi & 7,836 & & 34 & 0,000 \\
Sikap & 7,935 & & 34 & 0,000 \\
Kemkommat & 10,378 & & 34 & 0,000 \\
DI & $t_{\text {hitung }}$ & 2,032 & Df & Signifikan \\
Motivasi & 2,647 & & 34 & 0,012 \\
Sikap & 2,155 & & 34 & 0,038 \\
Kemkommat & 1,978 & & 34 & 0,056 \\
\hline
\end{tabular}

Berdasarkan Tabel 9 hasil uji tersebut, menunjukan bahwa nilai $t_{\text {hitung }}$ yang diperoleh untuk kelompok model ISK pada variabel motivasi belajar sebesar 7,836, variabel sikap siswa terhadap matematika sebesar 7,953, dan variabel kemampuan komunikasi matematis siswa sebesar 10,378 , lebih dari $\mathrm{t}_{\text {tabel }}$ yaitu $\mathrm{t}$ $(0,05 ; 34)=2,032$ sehingga dapat disimpulkan $\mathrm{H}_{\mathrm{o} 1}, \mathrm{H}_{\mathrm{o} 2}, \mathrm{H}_{\mathrm{0} 3}$ ditolak yang artinya pembelajaran matematika dengan model ISK efektif ditinjau dari motivasi belajar, sikap siswa terhadap matematika, dan kemampuan komunikasi matematis siswa dan signifikan karena perolehan nilai signifikannya $0,000<0,05$. Sedangkan untuk model DI diperoleh nilai $t_{\text {hitung }}$ pada variabel motivasi belajar sebesar 2,647 dan nilai $\mathrm{t}_{\text {hitung }}$ pada variabel sikap siswa terhadap matematika sebesar 2,978 lebih dari $\mathrm{t}_{\text {tabel }}=2,032$ maka disimpulkan $\mathrm{H}_{04}$ dan $\mathrm{H}_{05}$ ditolak artinya pembelajaran matematika dengan model DI efektif ditinjau dari motivasi belajar dan sikap siswa terhadap matematika dan signifikan karena nilai signifikansinya sebesar 0,012 dan 0,038<0,05, selanjutnya perolehan nilai $t_{\text {hitung }}$ pada variabel kemampuan komunikasi matematis siswa sebesar 1,978 < $\mathrm{t}_{\text {tabel }}=2,032$ maka disimpulkan $\mathrm{H}_{\mathrm{o} 6}$ diterima yang artinya pembelajaran matematika dengan model DI tidak efektif ditinjau dari kemampuan komunikasi matematis siswa dan tidak signifikan sebab perolehan nilai signifikannya sebesar $0,058>0,05$.

Untuk mengetahui model pembelajaran mana yang lebih efektif antara model pembelajaran ISK dan Model DI maka dilakukan uji univariat (independent samples t-test). Sebelum dianalisis dengan menggunakan independent samples t-test terlebih dahulu dilakukan uji perbedaan rata-rata terhadap data skor sebelum treatment menggunakan uji MANOVA dengan kriteria $T^{2}$ Hotelling's. Jika hasilnya menyimpulkan bahwa kedua kelas tidak berbeda, maka data skor yang dianalisis untuk membandingkan keefektifan pembelajaran dengan masing-masing model pembelajaran adalah data skor setelah treatment. Selanjutnya, uji MANOVA dengan kriteria $T^{2}$ Hotelling dapat dilakukan jika uji asumsi terpenuhi. Adapun uji asumsi yang harus dipenuhi adalah uji normalitas dan uji homogenitas.

Uji normalitas terhadap data sebelum dan setelah treatment yang digunakan adalah uji normalitas multivariat. Berdasarkan hasil perhitungan yang dilakukan secara manual dengan bantuan software office excel. Diperoleh jarak mahalanobis antara setiap pengamatan dengan vektor rata-rata setelah diurutkan, diperoleh hasil sebagai berikut. 
Tabel 10. Jarak Mahalanobis

\begin{tabular}{|c|c|c|c|}
\hline Kondisi & Model & Variabel & $\begin{array}{c}\text { Nilai } \\
d_{i}^{2}<\chi_{0,5(3)}^{2}\end{array}$ \\
\hline \multirow{2}{*}{$\begin{array}{l}\text { Sebelum } \\
\text { treatment }\end{array}$} & ISK & $\begin{array}{c}\text { Motivasi } \\
\text { Sikap } \\
\text { Kemkommat }\end{array}$ & $48,57 \%$ \\
\hline & DI & $\begin{array}{l}\text { Motivasi } \\
\text { Sikap } \\
\text { Kemkommat }\end{array}$ & $45,71 \%$ \\
\hline \multirow{2}{*}{$\begin{array}{l}\text { Setelah } \\
\text { treatment }\end{array}$} & ISK & $\begin{array}{c}\text { Motivasi } \\
\text { Sikap } \\
\text { Kemkommat }\end{array}$ & $45,71 \%$ \\
\hline & DI & $\begin{array}{c}\text { Motivasi } \\
\text { Sikap } \\
\text { Kemkommat }\end{array}$ & $51,42 \%$ \\
\hline
\end{tabular}

Tabel 10 menunjukkan jarak mahalanobis antara setiap pengamatan dengan vektor ratarata setelah diurutkan memiliki range yang tidak jauh dari 50\% maka dapat disimpulkan bahwa data sebelum dan setelah treatment pada kelompok model ISK dan DI berdistribusi normal multivariat.

Selanjutnya uji homogenitas dilakukan dengan menggunakan uji Box's $M$, diperoleh hasil sebagai berikut.

Tabel 11. Hasil Uji Homogenitas Menggunakan Box's $M$

\begin{tabular}{ccc}
\hline Kondisi & Variabel & Box's $\boldsymbol{M}$ (Sig.) \\
\hline Sebelum & Motivasi & \\
treatment & Sikap & 0,831 \\
& $\begin{array}{c}\text { Kemkommat } \\
\text { Motivasi }\end{array}$ \\
Setelah & $\begin{array}{c}\text { Sikap } \\
\text { treatment }\end{array}$ & 0,178 \\
& Kemkommat & \\
\hline
\end{tabular}

Berdasarkan Tabel 11 tersebut nilai signifikan lebih besar dari 0,05 maka disimpulkan bahwa matriks varians kovarians kedua populasi homogen. Uji asumsi data skor sebelum dan setelah treatment terpenuhi, maka dilanjutkan uji MANOVA.

Adapun hipotesis yang akan di uji dalam bagian ini, yakni:

$\mathrm{H}_{0}$ : Tidak terdapat perbedaan rata-rata skor antara model pembelajaran ISK dengan DI ditinjau dari motivasi belajar, sikap siswa terhadap matematika, dan kemampuan komunikasi matematis

$\mathrm{H}_{\mathrm{a}}$ : Terdapat perbedaan rata-rata skor antara model pembelajaran ISK dengan DI ditinjau dari motivasi belajar, sikap siswa terhadap matematika, dan kemampuan komunikasi matematis.
Secara statistik, hipotesis tersebut dapat disimbolkan:

$$
\begin{aligned}
& \mathrm{H}_{0}:\left(\begin{array}{l}
\mu_{11} \\
\mu_{21} \\
\mu_{31}
\end{array}\right)=\left(\begin{array}{l}
\mu_{12} \\
\mu_{22} \\
\mu_{32}
\end{array}\right) \text { lawan } \\
& \mathrm{H}_{\mathrm{a}}:\left(\begin{array}{l}
\mu_{11} \\
\mu_{21} \\
\mu_{31}
\end{array}\right) \neq\left(\begin{array}{l}
\mu_{12} \\
\mu_{22} \\
\mu_{32}
\end{array}\right)
\end{aligned}
$$

Hasil uji multivariat data pretest dan posttest dapat disajikan pada Tabel.12 berikut.

Tabel 12. Hasil Uji Multivariate Data Pretest dan Posttest Model Pembelajaran ISK dan DI

\begin{tabular}{cccc}
\hline Kondisi & Value & F & Sig. \\
\hline Pretest & .003 & $.073^{\mathrm{a}}$ & .974 \\
Posttest & .280 & $6,150^{\mathrm{a}}$ & .001 \\
\hline
\end{tabular}

Berdasarkan hasil uji multivariat pada Tabel 12 tersebut diperoleh signifikansi untuk Hotelling's Tracenya $>0,05$ yaitu sebesar 0,974 ini menunjukan bahwa $\mathrm{H}_{\mathrm{o}}$ diterima sehingga disimpulkan kondisi awal sebelum treatment tidak terdapat perbedaan rata-rata motivasi belajar, sikap siswa terhadap matematika, dan kemampuan komunikasi matematis siswa antara model pembelajaran ISK dan model pembelajaran DI. Selanjutnya karena tidak terdapat perbedaan rata-rata pada data pretest maka tidak perlu dilakukan uji lanjut terhadap data pretest. Sedangkan hasil uji multivariat pada data posttest menunjukan nilai $\mathrm{F}$ pada Hotelling's Tracenya adalah $6,150^{\mathrm{a}}$ dengan signifikansi $0,001<0,05$, sehingga pada taraf nyata $0,05 \mathrm{H}_{\mathrm{o}}$ ditolak artinya pada kondisi akhir setelah treatment terdapat perbedaan rata-rata motivasi belajar, sikap siswa terhadap matematika, dan kemampuan komunikasi matematis siswa pada kedua kelompok eksperimen atau dapat disimpulkan bahwa terdapat perbedaan keefektifan antara kelompok model pembelajaran ISK dan kelompok model pembelajaran DI ditinjau dari motivasi belajar siswa, sikap siswa terhadap matematika, dan kemampuan komunikasi matematis siswa.

Hasil uji multivariat pada data posttest menyimpulkan terdapat perbedaan rata-rata antara kelompok model pembelajaran ISK dan kelompok model pembelajaran DI ditinjau dari motivasi belajar, sikap siswa terhadap matematika, dan kemampuan komunikasi matematis siswa, maka dilakukan uji lanjut untuk melihat variabel mana yang berkontribusi terhadap 
perbedaan tersebut. Selanjutnya akan dilakukan uji lanjut independen sample t-test dengan kriteria Bonferroni.

Adapun hipotesis yang diuji untuk t-test adalah:

$\mathrm{H}_{0}: \mu_{11} \leq \mu_{12}$ (Model pembelajaran ISK tidak

lebih efektif daripada model pembelajaran

DI ditinjau dari motivasi belajar siswa).

$\mathrm{H}_{\mathrm{a}}: \mu_{11}>\mu_{12}$ (Model pembelajaran ISK lebih

efektif daripada model pembelajaran DI ditinjau dari motivasi belajar siswa).

$\mathrm{H}_{0}: \mu_{21} \leq \mu_{22}$ (Model pembelajaran ISK tidak

lebih efektif daripada model pembelajaran

DI ditinjau dari sikap siswa terhadap matematika).

Ha : $\mu_{21}>\mu_{22}$ (Model pembelajaran ISK lebih efektif daripada model pembelajaran DI ditinjau dari sikap siswa terhadap matematika).

H0 : $\mu_{31} \leq \mu_{32}$ (Model pembelajaran ISK tidak lebih efektif daripada model pembelajaran DI ditinjau dari kemampuan komunikasi matematis siswa).

Ha : $\mu_{31}>\mu_{32}$ (Model pembelajaran ISK lebih efektif daripada model pembelajaran DI ditinjau dari kemampuan komunikasi matematis siswa).

Hasil uji univariat dengan kriteria Bonferroni secara ringkas dapat disajikan pada Tabel 13 berikut.

Tabel 13. Hasil Uji Univariat Menggunakan Independent Samples t-test

\begin{tabular}{cccc}
\hline Variabel & $\mathbf{t}_{\text {hitung }}$ & $\mathbf{t}_{\text {tabel }}$ & Sig. \\
\hline Motivasi & 2,924 & & .005 \\
Sikap & 3,014 & 2,455 & .003 \\
Kemkommat & 4,292 & & .001 \\
\hline
\end{tabular}

Berdasarkan hasil perhitungan pada Tabel 13 diperoleh $t_{\text {hitung }}$ untuk variabel motivasi belajar siswa 2,924 $>t_{\text {tabel }}=2,455$ sehingga $H_{0}$ ditolak. Oleh karena itu dapat disimpulkan bahwa model pembelajaran ISK lebih efektif daripada model DI ditinjau dari motivasi belajar siswa. Selanjutnya perolehan $t_{\text {hitung }}$ untuk variabel sikap siswa terhadap matematika adalah $3,014>t_{\text {tabel }}=2,455$ sehingga $H_{0}$ ditolak. Oleh karena itu dapat disimpulkan bahwa model pembelajaran ISK lebih efektif daripada model pembelajaran DI ditinjau dari sikap siswa terhadap matematika dan hasil perolehan nilai $t_{\text {hitung }}$ untuk variabel kemampuan komunikasi matematis adalah 4,292 > $t_{\text {tabel }}=2,455$ sehingga disimpulkan $H_{0}$ ditolak artinya model pembelajaran ISK lebih efektif daripada pembelajaran model DI ditinjau dari kemampuan komunikasi matematis siswa.

Hasil analisis yang menunjukan bahwa model ISK lebih efektif daripada model pembelajaran DI di pengaruhi oleh penerapan model pembelajaran terhadap ketiga aspek tersebut. Dimana pada model DI aktivitas siswa lebih didominasi oleh aktivitas mendengar penjelasan guru, membuat catatan dan mengerjakan tugas yang diberikan guru. Sementara pada pembelajaran model ISK lebih memungkinkan terjadinya berbagai aktifitas aktif siswa. Siswa tidak hanya menjadi pendengar, tetapi juga terlibat aktif seperti memecahkan masalah, mengajukan pertanyaan, mengemukakan pendapat, membantu memberikan penjelasan pada temannya, dan aktifitas berpikir. Keterlibatan siswa dalam berbagai aktifitas tersebut memungkinkan penguasaan siswa terhadap bahan ajar menjadi lebih baik, demikian pula dengan kemampuan komunikasi matematis siswa, motivasi belajar siswa, dan sikap siswa terhadap matematika.

Perbedaan situasi pada kedua model pembelajaran tersebut memberikan implikasi pada motivasi belajar siswa, sikap siswa terhadap matematika, dan kemampuan komunikasi matematis siswa. Sehingga motivasi belajar siswa, sikap siswa terhadap matematika, dan kemampuan komunikasi matematis siswa yang diajar dengan menggunakan model pembelajaran ISK lebih baik daripada motivasi belajar siswa, sikap siswa terhadap matematika, dan kemampuan komunikasi matematis siswa yang diajar dengan menggunakan model pembelajaran DI.

\section{SIMPULAN DAN SARAN}

\section{Simpulan}

Penelitian ini menunjukan bahwa model pembelajaran ISK efektif ditinjau dari motivasi belajar siswa, sikap siswa terhadap matematika, dan kemampuan komunikasi matematis siswa. Sedangkan model pembelajaran DI efektif ditinjau dari motivasi belajar siswa dan sikap siswa terhadap matematika, tetapi tidak efektif ditinjau dari kemampuan komunikasi matematis siswa SMA Negeri 3 Ternate. Serta model pembelajaran ISK lebih baik bila dibandingkan 
dengan model pembelajaran DI ditinjau dari motivasi belajar siswa, sikap siswa terhadap matematika, dan kemampuan komunikasi matematis siswa.

\section{Saran}

Berdasarkan hasil dan temuan penelitian, saran yang dapat disampaikan adalah sebagai berikut: (1) Disarankan kepada para guru matematika untuk berinovasi dalam pembelajaran matematika dengan menerapkan model pembelajaran ISK, sehingga dapat meningkatkan motivasi belajar siswa, sikap siswa terhadap matematika, dan kemampuan komunikasi matematis siswa yang pada akhirnya dapat meningkatkan prestasi belajar matematika siswa. (2) Disarankan pada peneliti yang berminat untuk menerapkan model pembelajaran ISK pada materi yang lain sehingga dapat memberikan bukti yang lebih kuat mengenai keefektifan model pembelajaran tersebut.

\section{DAFTAR PUSTAKA}

Azwar, S. (2008). Sikap manusia: teori dan pengukurannya. Yogyakarta: Pustaka pelajar offset.

Brown, T., \& McNamara, O. (2011). Becoming a mathematics teacher identivity and identification. London: Springer.

Depdiknas. (2006). Peraturan Menteri Pendidikan Nasional RI Nomor 22, tentang Standar Isi.

Depdiknas. (2007). Peraturan Menteri Pendidikan Nasional RI Nomor 41 tahun 2007 tentang standar proses.

Killen, R. (2009). Effective teaching strategies : lessons from research and practice $\left(5^{\text {th }}\right.$ ed.). China: C \& $\mathrm{C}$ Offset Printing Co.Ltd.

Mahmudi, A. (2009). Komunikasi dalam pembelajaran matematika. Jurnal MIPMIPA
UNHALU. Volume 8, Nomor 1, Februari 2009.

Muijs, D. \& Reynolds, D. (2005). Effective teaching evidence and practice. London: SAGE Publications.

NCTM. (2000). Principles and standards for school mathematics. Reston, VA: National Council of Teachers of Mathematics.

Popham, W.J. (1995). Classroom assessment: what teachers need to know. Needham Heights, Mass: Allyn and Bacon.

Republik Indonesia. 2003). Undang-Undang RI Nomor 20, tahun 2003 tentang Sistem Pendidikan Nasional.

Sagala, S. (2010). Konsep dan Makna Pembelajaran. Bandung: CV Alfabeta.

Sanjaya, W. (2010). Strategi pembelajaran berorientasi standar proses pendidikan. Jakarta: Kencana.

Santrock, J.W. (2008). Educational psychology, $5^{\text {th }}$ edition. New York: McGrow-Hill Companies.

Shunway, R.J. (1980). Research in mathematics education. New York: Macmillan College Publishing Company.

Stevens, J. (2002). Applied multivariate statistics for the social sciences. New York: Taylor \& Francis Group

Van de Walle, J.A. (2008). Matematika Sekolah Dasar dan menengah (Terjemahan Suyono). Jakarta: Penerbit Erlangga. (buku asli diterbitkan tahun 2007).

Zakaria, E., \& Iksan, Z. (2007). Promoting cooperative learning in science and mathematics education: A malaysian perspective. Euresia Journal of Mathematics, Science \& Technology Education, 2007, 3(1), 35-39. 